\title{
In Vitro Study Regarding the Biomechanical Behaviour of Bone, Fibre Reinforced Polymer and Wire Composite Periodontal Splints. II.Model Analysis
}

\author{
RALUCA MARIA VIERIU1(ⓗttps://orcid.org/0000-0002-2564-3884), \\ OANA TANCULESCU ${ }^{2} *$ (D https://orcid.org/0000-0002-0087-7190), \\ FLORENTINA MOCANU ${ }^{3 *}$, SORINA MIHAELA SOLOMON², CARMEN SAVIN ${ }^{1}$, \\ DANA GABRIELA BOSINCEANU ${ }^{4}$, ADRIAN DOLOCA ${ }^{5}$, CRISTINA IORDACHE ${ }^{1}$, \\ GABRIELA IFTENI ${ }^{1}$, IULIA SAVEANU ${ }^{1}$
}

${ }^{1}$ Grigore T. Popa University of Medicine and Pharmacy, Faculty of Dental Medicine, Department of Oral and Maxillofacial Surgery, 16 Universitatii Str., 700115, Iasi, Romania

${ }^{2}$ Grigore T. Popa University of Medicine and Pharmacy, Faculty of Dental Medicine, Department of OdontologyPeriodontology, Fixed Prosthodontics, 16 Universitatii Str., 700115, Iasi, Romania

${ }^{3}$ Gheorghe Asachi Technical University of Iasi, Faculty of Mechanical Engineering, 71 D. Mangeron Blvd., 700050, Iasi, Romania

${ }^{4}$ Grigore T. Popa University of Medicine and Pharmacy, Faculty of Dental Medicine, Department of Implantology, Removable Dentures, Technology of Dental Prosthesis, 16 Universitatii Str., 700115, Iasi, Romania

${ }^{5}$ Grigore T. Popa University of Medicine and Pharmacy, Faculty of Dental Medicine, Department of Preventive Medicine and Interdisciplinarity, 16 Universitatii Str., 700115, Iasi, Romania

\begin{abstract}
This paper is the second part of a study regarding the biomechanical behaviour of mandibular bone in the context of different periodontal splinting systems, occlusal forces and load distributions. Electric resistive tensometry method was used to measure the strains developed in mandibular bone replica. The tests were carried out on six mandibular acrylic models, each with 8 natural teeth. The experimental groups were defined corresponding to the bone condition and splint type: normal height bone; bone resorption without splint; bone resorption and wire-composite splint; bone resorption and polyethylene fiber-reinforced composite splint. Each sample was subjected to three similar loading cycles, the force being applied successively on four incisors, two central incisors and canines, and the specific deformation values were read for four loading forces: $30 \mathrm{~N}, 50 \mathrm{~N}, 100 \mathrm{~N}$ and $150 \mathrm{~N}$. In case of bone loss, the bone deformations are up to 110\%. Periodontal splinting redistribute forces, reducing incisors bone strains associated with a slight increase in canine bone strains.
\end{abstract}

Keywords: periodontal splint, bone strain, electric resistive tensometry, fibre-reinforced composite

\section{Introduction}

Periodontitis is a chronic infectious disease of the tissues surrounding the teeth caused by specific microorganisms or groups of specific microorganisms, characterized by gingival inflammation, loss of connective tissue attachment and destruction of alveolar bone [1-3]. With the reduction of periodontal attachment, mobility and dental migration appear, resulting in incorrectly distributed occlusal forces, which overload the already affected periodontal system. The relationship between occlusal trauma and tooth mobility depends on the intensity and frequency of occlusal forces [4].

The treatment of dental mobility in periodontal disease is determined by the degree of bone resorption. For teeth with increased mobility due to widening of periodontal space induced by the adaptation to the functional conditions of mastication, the treatment is a combination of occlusal adjustments and periodontal therapy. For teeth affected by gingival inflammation and increased mobility due to bone resorption, the treatment is a combination of periodontal therapy, occlusal adjustments and teeth immobilization [5-9]. Stabilization is achieved by periodontal splinting, which

*email: ot@umfiasi.ro, florentinamoc@yahoo.com All authors have equally contributed to this work. 
leads to redistribution of functional and para-functional occlusal forces. This helps the reorganization of the gum tissues, the periodontal fibers and the alveolar bone, consequently improving the masticatory and patient comfort $[10,11]$. The use of periodontal splint before the surgical treatment improves the predictability of the procedures and the tissues healing if the tooth movement is eliminated [12].

There are numerous immobilization systems: composite resins $[6,13,14]$, wire mesh [13,15], fiberreinforced composites $[6,13,16]$.

While the clinical rational for splinting is less disputable in current scientific literature [16-21], the latest advances in splinting materials and the wide variety available [22] can create confusion among practitioners. There is even less information regarding the biomechanical response of the periodontal complex in the context of different bone resorptions and splints [23-33]. These aspects make splinting therapy to be a challenging decision for dental professionals.

The purpose of the study was to evaluate the biomechanical behaviour of mandibular bone by means of electric resistive tensometry method, in case of different periodontal splinting systems subjected to different occlusal forces. The method was described in the first part of this research, in a previous paper [34]. The premise of this research wa that the degree of the bone resorption and the type of the periodontal splint influence the tooth displacements and, consequently, the deformation of the mandibular bone, resulted in the recorded strain values.

\section{Materials and methods}

\subsection{Mandibular acrylic models}

The tests were carried out on six mandibular acrylic models (Duracryl Plus, Spofa Dental, Czech Republic, No. Batch: 2373741). The fabrication and validation of the models were previously described in detail [34]. In brief, each model comprised of eight extracted mandibular teeth, from the first right premolar, to the first left premolar. The periodontal ligament was replicated with a fluid condensation silicone (Oranwash L, Zhermack, batch No. 192139).

After performing mechanical tests on the initial model with bone integrity (normal height bone NHB), $5 \mathrm{~mm}$ and $4.5 \mathrm{~mm}$ acrylate removal was performed on CIs and LIs, respectively, corresponding to bone resorption (BR) in marginal periodontitis. The mobility Periotest values (PTVs) of CIs and LIs were greater than 30 units, which justified the application of periodontal splinting.

\subsection{Periodontal splints}

The materials used for the periodontal splints are shown in Table 1. Construct (Kerr UK Ltd, Peterborough) is an ultra-high strength polyethylene fibre that has been cold gas plasma-treated and is pre-silanated with unfilled resin. Premise is a light-cured resin composite containing three different sized filler particles (tri-modal): prepolymerized fillers, 30-50 microns; bari-um glass, 0.4 microns; and silica nanoparticles, 0.02 microns.

Table 1. Materials used for dental splinting

\begin{tabular}{|c|c|c|c|}
\hline Material & Producer & Batch no. & Type of material \\
\hline Construct & Kerr & 5102784 & Non-impregnated woven polyethylene fiber $2 \mathrm{~mm}$ \\
\hline Construct & Kerr & 5100456 & Impregnating resin \\
\hline Premise Packable & Kerr & 4957927 & Nanofilled restorative composite packable \\
\hline Premise Flow & Kerr & 5123370 & Nanofilled restorative composite flow \\
\hline Wildcat .0195" & Dentsply GAC & 171245 & Twisted stainless steel wire \\
\hline OptiBond XTR Adhesive & Kerr & 4788988 & Adhesive \\
\hline Pegasus etchant gel & Astek Innovations & 1209132 & Orthophosphoric acid 37\% \\
\hline Light-curing unit & Woodpecker & & $\begin{array}{c}\text { Luminous intensity of } 1200 \mathrm{~mW} / \mathrm{cm}^{2} \text {; wavelength of } 430-480 \\
\mathrm{~nm}\end{array}$ \\
\hline
\end{tabular}

The first splinting system was wire-composite resin (WRC). The steps were as follows: (1) measuring the inter-canine distance and cutting the appropriate length of the twisted wire; (2) adapting 
and conforming the wire on the model; (3) degreasing of lingual surfaces; (4) etching of lingual and proximal accessible surfaces with orthophosphoric acid $37 \%$ for 30 seconds; (5) acid removal, surface washing and drying; (6) applying of the adhesive and light cure for 20 seconds / tooth with the tip of the light beam placed at a distance of $5 \mathrm{~mm}$ from the sample; (7) wire positioning and applying of the packable composite layer at the level of each tooth, followed by light curing for 40 seconds / tooth (Figure 1).
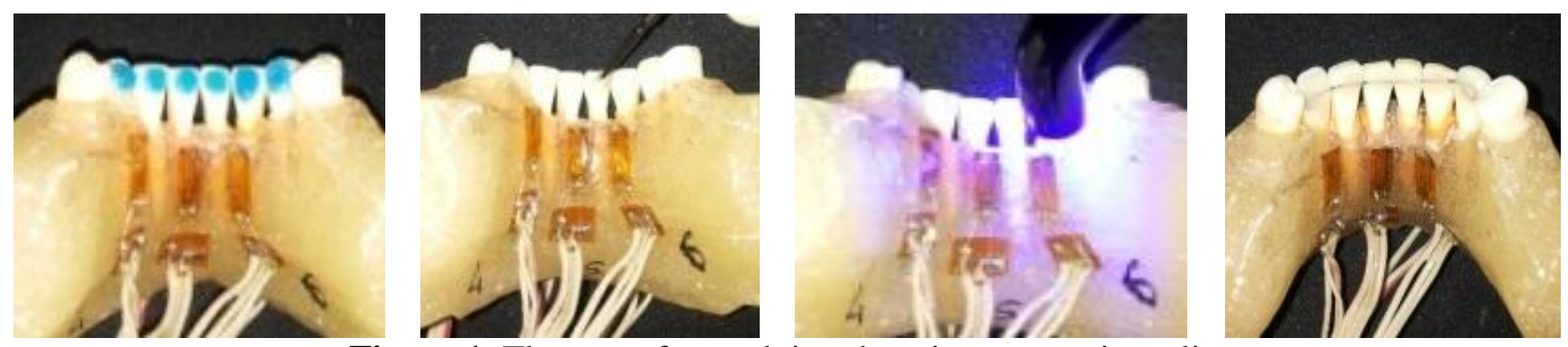

Figure 1. The steps for applying the wire-composite splint

After performing the mechanical tests on the wire-composite splint model, the splint was carefully removed in order to avoid the damage of the model and of the strain gauges.

The second immobilization system was the polyethylene fiber composite (FC). The steps were as follows: (1) measuring the inter-canine distance and cutting the corresponding strip of fiber band; (2) impregnation of the polyethylene fiber with the Construct resin; (3) degreasing of lingual surfaces; (4) etching of lingual surfaces with orthophosphoric acid $37 \%$ for 30 seconds; (5) acid removal, surface washing and drying; (6) adhesive applying and light curing for 20 seconds / tooth; (7) applying of a 0.2 mm layer of Premise composite; (8) adapting the impregnated polyethylene fiber and removing the excess of composite; (9) light-curing for 40 seconds / tooth; (10) applying a final layer of Premise flow composite to fully covering the fiber and light curing for 40 seconds / tooth (Figure 2).
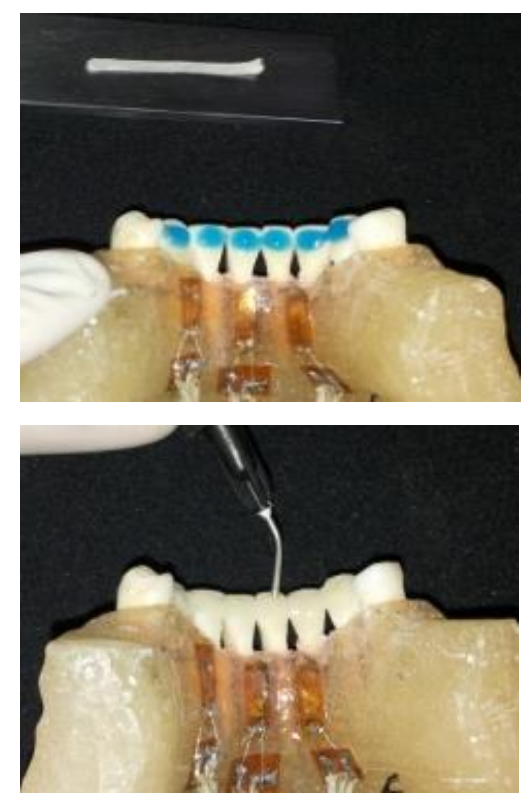
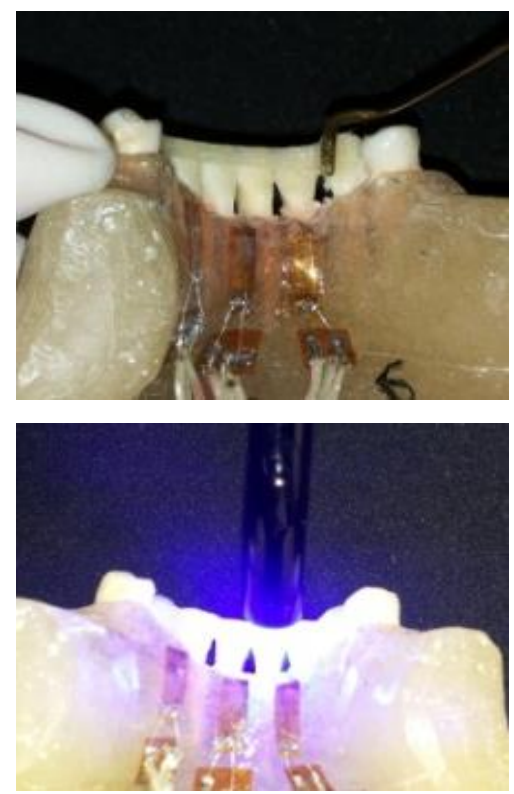
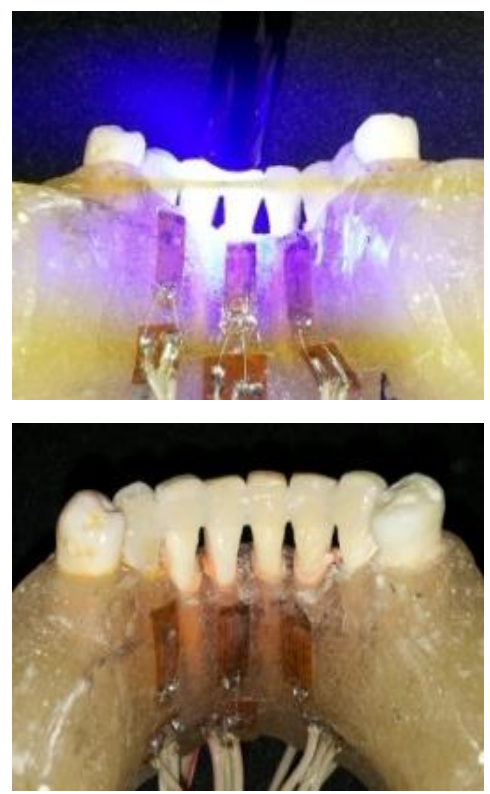

Figure 2. The steps for applying the polyethylene fiber composite splint

\subsection{Mechanical testing of the samples}

The mechanical testing protocol was also described in detail in the first part of this study [34]. It is presented briefly below. 
$6 \mathrm{~mm}$ length and $2 \mathrm{~mm}$ width strain gauges (SG) (EA-06-240LZ-120/E, Micro-Measurements Group, Vishay, Batch No.: R-A59AF524) were selected for quantifying the bone deformation. Their electrical resistance was $120 \pm 0.03 \Omega$ at $24^{\circ} \mathrm{C}$. They were placed on the mandibular replica, corresponding to coronal-radicular axis as it follows: three on the buccal surface (SG 1 - right lateral incisor/RLI, SG 2 - left central incisor/LCI, SG 3 - left canine/LC) and three on the lingual surface (SG 4 - LC, SG 5 - LCI, SG 6 - RLI). A WDW-5CE High Performance Electronic Universal Testing Machine (Bairoe, Shanghai, China) was used to perform the compression tests and record the timeforce variation. With a specially adapted device, the model was mounted on the test machine allowing an occlusal load orientation of $135^{\circ}$ on the mandibular incisors that replicated the normal interincisal angle, and an individual loading on incisors and canines.

The load distribution was at the level of: (i) four incisors - 4I; (ii) two central incisors - 2I; (iii) canine - C. The samples were three times tested for each load distribution, with a load speed of $0.5 \mathrm{~mm}$ / min, $150 \mathrm{~N}$ maximum load, at room temperature $\left(23^{\circ} \mathrm{C}\right)$ and with a 5 minute break before each test to allow for recalibration of the marks. The specific deformations provided by the strain gauges (in relation to time) were recorded with two strain gauge bridges P3 model (Vishay). The displacement values were read for the four loading forces: $30 \mathrm{~N}, 50 \mathrm{~N}, 100 \mathrm{~N}$ and $150 \mathrm{~N}$, respectively.

A dial comparator was positioned in contact with the labial middle third of RLI, which allowed the horizontal tooth displacement measurements with an accuracy of $\pm 0.01 \mathrm{~mm}$ (Figure 3 ).

The experimental groups were defined corresponding to the bone condition and splint type as it follows: models with normal height bone (NHB); models with bone resorption without splint (BR); models with bone resorption and wire-composite splint (WRC); models with bone resorption and polyethylene fiber-reinforced composite splint (FRC). Each sample was subjected to three similar loading cycles, the force being applied successively on 4I, 2I and C, and the specific deformation values expressed in $\mu \varepsilon$ (equivalent to $\mu \mathrm{m} / \mathrm{m}$ ) were read for four loading forces: $30 \mathrm{~N}, 50 \mathrm{~N}, 100 \mathrm{~N}$ and $150 \mathrm{~N}$.

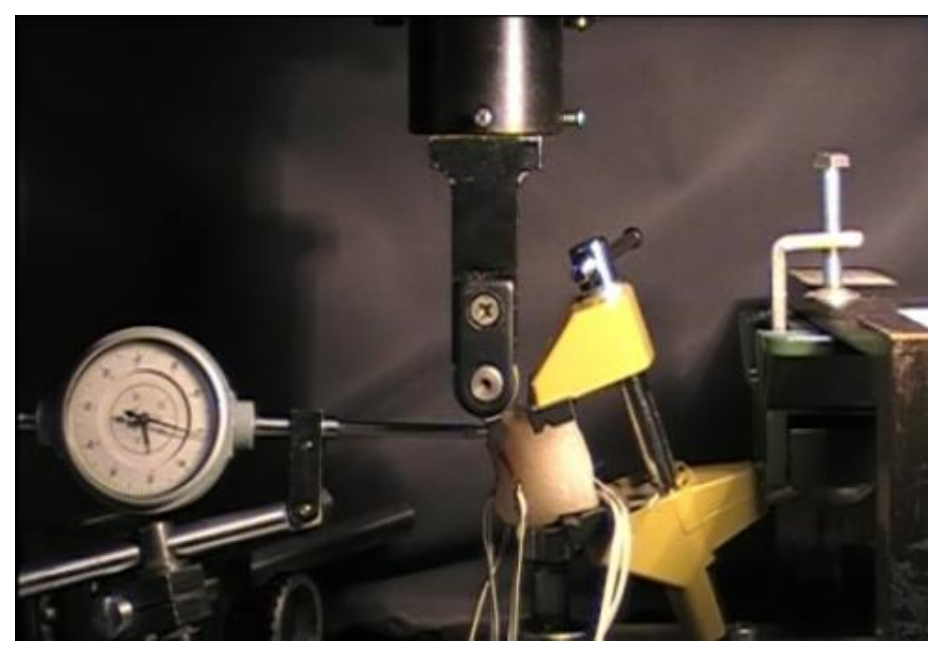

Figure 3. Positioning the model on the machine support

\subsection{Statistical analysis}

Statistical data analysis was performed with STATISTICA 11.0 (Stat-Soft, Tulsa, OK), at a significance level of 0.05 . Factorial analysis of variance (ANOVA) was employed to evaluate the effect of four variables: bone condition and splint type (BC), mandibular bone surface (BS), load distribution (LD), and tooth position (T) on the bone strain in the context of different occlusal loading.

\section{Results and discussions}

The dental mobility was re-evaluated after applying each immobilization system and the results are presented in Table 2. 
The horizontal displacement values of RLI are presented in Table 3.

Bone strains values expressed in $\mu \varepsilon$ (equivalent with $\mu \mathrm{m} / \mathrm{m}$ ) for every situation referred above were read for the four forces $30 \mathrm{~N}, 50 \mathrm{~N}, 100 \mathrm{~N}$ and $150 \mathrm{~N}$ (Table 4).

Table 2. The means (standard deviations) of PTVs on the model with bone resorption and splint

\begin{tabular}{|c|c|c|c|c|c|c|c|c|}
\hline Tooth & RP & RC & RLI & RCI & LCI & LLI & LC & LP \\
\hline BR & $1.0(0.2)$ & $-1.0(0.5)$ & $27.3(1.5)$ & $34.7(2.5)$ & $41.3(2.5)$ & $28(2.0)$ & $-0,8(0.2)$ & $0.1(0.4)$ \\
\hline WRC & $1(0.2)$ & $-0,8(0.3)$ & $2(0.1)$ & $3(0.3)$ & $4(0.2)$ & $3(0.4)$ & $1,1(0.4)$ & $0,1(0.1)$ \\
\hline FRC & $1(0.2)$ & $-1(0.2)$ & $1,6(0.2)$ & $2(3)$ & $3,4(0.1)$ & $0,4(0.0)$ & $0,8(0.2)$ & $0,1(0.0)$ \\
\hline
\end{tabular}

$R P=$ right premolar $; R C=$ right canine $; R L I=$ right lateral incisor $; R C I=$ right central incisor $; L C I=$ left central incisor $;$

$L L I=$ left lateral incisor; $L C=$ left canine; $L P=$ left premolar; $B R=$ bone resorption, $W R C=$ wire-composite splint; $F R C=$ fiber-reinforced composite splint [34].

Table 3. The horizontal displacement values of RLI ( $\mathrm{mm}$ )

\begin{tabular}{|c|c|c|c|c|c|c|c|c|c|c|c|c|c|}
\hline \multirow{2}{*}{\multicolumn{2}{|c|}{$\begin{array}{l}\text { Load } \\
(\mathrm{N})\end{array}$}} & \multicolumn{3}{|l|}{ NHB } & \multicolumn{3}{|l|}{ RB } & \multicolumn{2}{|c|}{ WRC } & \multicolumn{4}{|c|}{ FRC } \\
\hline & & $4 \mathrm{I}$ & $2 \mathrm{I}$ & C & $4 \mathrm{I}$ & $2 \mathrm{I}$ & C & $4 \mathrm{I}$ & 2 I & C & $4 \mathrm{I}$ & $2 I$ & C \\
\hline \multirow[b]{2}{*}{0} & 3 Mean & 0 & 0.01 & 0 & 0.05 & 0.45 & 0 & 0.01 & 0.02 & 0 & 0 & 0.05 & 0 \\
\hline & SD & 0 & 0.0005 & 0 & 0.0035 & 0.045 & 0 & 0.0014 & 0.0028 & 0 & 0 & 0.0025 & 0 \\
\hline \multirow{3}{*}{0} & 5 Mean & 0.01 & 0.033 & 0 & 0.25 & 0.95 & 0 & 0.02 & 0.04 & 0 & 0.013 & 0.035 & 0 \\
\hline & SD & 0.002 & 0.006 & 0.000 & 0.053 & 0.238 & 0.000 & 0.000 & 0.001 & 0.000 & 0.002 & 0.006 & 0.000 \\
\hline & 1 Mean & 0.015 & 0.043 & 0.008 & 0.96 & 1.28 & 0.05 & 0.045 & 0.051 & 0.01 & 0.018 & 0.045 & 0.01 \\
\hline \multirow[t]{2}{*}{00} & $S D$ & 0.003 & 0.006 & 0.000 & 0.030 & 0.143 & 0.000 & 0.001 & 0.006 & 0.000 & 0.002 & 0.006 & 0.000 \\
\hline & 1 Mean & 0.040 & 0.055 & 0.01 & 1.17 & 1.55 & 0.2 & 0.03 & 0.066 & 0.025 & 0.028 & 0.06 & 0.015 \\
\hline 50 & $S D$ & 0.002 & 0.007 & 0.001 & 0.176 & 0.388 & 0.044 & 0.006 & 0.009 & 0.001 & 0.002 & 0.013 & 0.003 \\
\hline
\end{tabular}

$I=$ incisor $; C=$ canine $; N H B=$ normal height bone; $B R=$ bone resorption; $W R C=$ wire-composite splint $;$ FRC $=$ fiber-reinforced composite splint; $S D=$ standard deviation

Table 4. Bone strains values $(\mu \varepsilon)$ for the four compression loads

\begin{tabular}{|c|c|c|c|c|c|c|c|c|c|c|c|c|c|c|}
\hline \multirow{2}{*}{ Force } & \multirow{2}{*}{ Group } & \multirow{2}{*}{ Contac } & \multicolumn{2}{|l|}{ SG 1} & \multicolumn{2}{|l|}{ SG 2} & \multicolumn{2}{|l|}{ SG 3} & \multicolumn{2}{|l|}{ SG 4} & \multicolumn{2}{|l|}{ SG 5} & \multicolumn{2}{|l|}{ SG 6} \\
\hline & & & Mean & SD & Mean & $S D$ & Mean & $S D$ & Mean & $S D$ & Mean & $S D$ & Mean & $S D$ \\
\hline \multirow{12}{*}{30} & \multirow{3}{*}{ NHB } & $4 I$ & 92 & 10.12 & 151 & 6.04 & 15 & 0.30 & 13 & 2.99 & 110 & 16.50 & 65 & 8.45 \\
\hline & & 2I & 13 & 2.99 & 298 & 53.64 & 10 & 0.60 & 9 & 0.99 & 260 & 7.80 & 10 & 2.00 \\
\hline & & C & 21 & 5.04 & 30 & 3.00 & 557 & 44.56 & 532 & 15.96 & 22 & 5.50 & 13 & 0.65 \\
\hline & \multirow{3}{*}{ BR } & $4 \mathrm{I}$ & 143 & 20.02 & 250 & 50.00 & 16 & 4.00 & 13 & 2.21 & 178 & 35.60 & 110 & 4.40 \\
\hline & & 2I & 32 & 5.44 & 547 & 54.70 & 12 & 1.20 & 10 & 0.70 & 486 & 68.04 & 28 & 2.52 \\
\hline & & C & 20 & 4.00 & 31 & 2.48 & 579 & 115.80 & 561 & 22.44 & 22 & 4.62 & 10 & 0.40 \\
\hline & \multirow{3}{*}{ FRC } & $4 \mathrm{I}$ & 102 & 20.40 & 150 & 19.50 & 35 & 5.95 & 31 & 4.96 & 108 & 3.24 & 66 & 13.86 \\
\hline & & 2I & 66 & 15.84 & 191 & 30.56 & 33 & 5.94 & 30 & 6.30 & 180 & 28.80 & 48 & 6.72 \\
\hline & & C & 80 & 3.20 & 110 & 12.10 & 534 & 85.44 & 518 & 62.16 & 100 & 17.00 & 70 & 3.50 \\
\hline & \multirow{3}{*}{ WRC } & 4I & 91 & 10.01 & 149 & 5.96 & 32 & 1.60 & 28 & 3.92 & 108 & 8.64 & 64 & 10.88 \\
\hline & & 2I & 58 & 4.06 & 187 & 35.53 & 28 & 5.88 & 27 & 3.51 & 166 & 6.64 & 47 & 7.05 \\
\hline & & C & 95 & 7.60 & 114 & 25.08 & 540 & 10.80 & 525 & 10.50 & 105 & 15.75 & 87 & 9.57 \\
\hline \multirow{12}{*}{50} & \multirow{3}{*}{ NHB } & $4 \mathrm{I}$ & 123 & 30.75 & 205 & 12.30 & 17 & 3.40 & 14 & 2.10 & 153 & 16.83 & 92 & 21.16 \\
\hline & & 2I & 23 & 4.83 & 400 & 88.00 & 10 & 1.60 & 10 & 2.20 & 361 & 14.44 & 16 & 2.56 \\
\hline & & C & 29 & 4.06 & 34 & 1.70 & 689 & 144.69 & 673 & 94.22 & 26 & 2.34 & 17 & 2.89 \\
\hline & \multirow{3}{*}{ BR } & 4I & 202 & 46.46 & 357 & 24.99 & 18 & 1.26 & 14 & 0.56 & 262 & 10.48 & 157 & 12.56 \\
\hline & & 2I & 39 & 8.19 & 730 & 87.60 & 14 & 0.98 & 11 & 0.66 & 647 & 161.75 & 37 & 6.66 \\
\hline & & C & 31 & 4.65 & 47 & 6.58 & 715 & 21.45 & 702 & 56.16 & 32 & 5.12 & 19 & 2.28 \\
\hline & \multirow{3}{*}{ FRC } & 4I & 131 & 13.10 & 229 & 20.61 & 54 & 3.78 & 43 & 9.03 & 162 & 34.02 & 101 & 6.06 \\
\hline & & 2I & 88 & 11.44 & 314 & 69.08 & 49 & 9.80 & 43 & 8.60 & 273 & 8.19 & 65 & 13.65 \\
\hline & & C & 107 & 18.19 & 131 & 9.17 & 665 & 139.65 & 634 & 19.02 & 120 & 10.80 & 98 & 14.70 \\
\hline & \multirow{3}{*}{ WRC } & 4I & 126 & 10.08 & 203 & 26.39 & 53 & 2.65 & 41 & 8.61 & 151 & 24.16 & 90 & 5.40 \\
\hline & & 2I & 85 & 19.55 & 303 & 60.60 & 46 & 10.58 & 40 & 5.60 & 259 & 5.18 & 62 & 7.44 \\
\hline & & C & 113 & 24.86 & 134 & 30.82 & 670 & 26.80 & 642 & 25.68 & 125 & 5.00 & 105 & 22.05 \\
\hline \multirow{6}{*}{100} & \multirow{3}{*}{ NHB } & 4I & 230 & 9.20 & 421 & 29.47 & 19 & 1.33 & 15 & 2.70 & 337 & 6.74 & 194 & 27.16 \\
\hline & & 2I & 38 & 1.90 & 800 & 200.00 & 12 & 2.88 & 13 & 2.73 & 680 & 47.60 & 23 & 1.38 \\
\hline & & C & 35 & 4.90 & 40 & 0.80 & 982 & 206.22 & 964 & 134.96 & 32 & 7.04 & 19 & 0.95 \\
\hline & \multirow{3}{*}{ BR } & 4I & 365 & 47.45 & 661 & 125.59 & 21 & 2.52 & 18 & 1.08 & 541 & 129.84 & 314 & 47.10 \\
\hline & & 2I & 54 & 13.50 & 1390 & 97.30 & 15 & 2.40 & 15 & 1.65 & 1182 & 130.02 & 41 & 6.56 \\
\hline & & C & 41 & 6.15 & 49 & 2.45 & 1019 & 203.80 & 989 & 49.45 & 39 & 7.80 & 25 & 4.50 \\
\hline
\end{tabular}




\begin{tabular}{|c|c|c|c|c|c|c|c|c|c|c|c|c|c|c|}
\hline & \multirow{3}{*}{ FRC } & $4 \mathrm{I}$ & 244 & 12.20 & 452 & 40.68 & 81 & 3.24 & 77 & 6.16 & 340 & 34.00 & 238 & 40.46 \\
\hline & & 2I & 129 & 25.80 & 608 & 91.20 & 79 & 6.32 & 64 & 10.24 & 574 & 74.62 & 92 & 2.76 \\
\hline & & C & 130 & 5.20 & 162 & 37.26 & 913 & 219.12 & 896 & 107.52 & 131 & 13.10 & 83 & 8.30 \\
\hline & \multirow{3}{*}{ WRC } & $4 I$ & 237 & 52.14 & 405 & 60.75 & 80 & 4.80 & 75 & 5.25 & 327 & 45.78 & 195 & 46.80 \\
\hline & & $2 I$ & 131 & 9.17 & 588 & 99.96 & 74 & 9.62 & 61 & 10.98 & 565 & 107.35 & 93 & 22.32 \\
\hline & & C & 139 & 27.80 & 173 & 25.95 & 921 & 119.73 & 904 & 117.52 & 138 & 5.52 & 88 & 2.64 \\
\hline \multirow{12}{*}{150} & \multirow{3}{*}{ NHB } & $4 I$ & 330 & 36.30 & 616 & 73.92 & 21 & 2.31 & 16 & 3.52 & 510 & 45.90 & 281 & 50.58 \\
\hline & & 2I & 49 & 9.80 & 1170 & 152.10 & 12 & 0.36 & 14 & 0.84 & 1014 & 233.22 & 37 & 8.88 \\
\hline & & C & 44 & 4.40 & 52 & 9.36 & 1287 & 102.96 & 1279 & 217.43 & 48 & 12.00 & 34 & 7.48 \\
\hline & \multirow{3}{*}{ BR } & $4 \mathrm{I}$ & 542 & 59.62 & 962 & 192.40 & 23 & 5.52 & 20 & 2.60 & 813 & 186.99 & 471 & 108.33 \\
\hline & & 2I & 64 & 10.24 & 1710 & 51.30 & 17 & 2.38 & 16 & 2.40 & 1528 & 229.20 & 52 & 6.24 \\
\hline & & C & 52 & 9.88 & 59 & 2.95 & 1321 & 66.05 & 1294 & 38.82 & 48 & 10.56 & 36 & 3.60 \\
\hline & \multirow{3}{*}{ FRC } & $4 I$ & 362 & 28.96 & 664 & 33.20 & 110 & 18.70 & 91 & 2.73 & 548 & 98.64 & 401 & 84.21 \\
\hline & & 2I & 148 & 23.68 & 910 & 118.30 & 92 & 16.56 & 88 & 3.52 & 782 & 132.94 & 123 & 17.22 \\
\hline & & C & 193 & 17.37 & 215 & 30.10 & 1204 & 108.36 & 1183 & 260.26 & 180 & 19.80 & 162 & 30.78 \\
\hline & \multirow{3}{*}{ WRC } & $4 I$ & 329 & 19.74 & 610 & 73.20 & 110 & 23.10 & 82 & 16.40 & 508 & 66.04 & 282 & 50.76 \\
\hline & & $2 \mathrm{I}$ & 154 & 12.32 & 915 & 100.65 & 89 & 19.58 & 87 & 20.88 & 779 & 54.53 & 134 & 33.50 \\
\hline & & C & 201 & 28.14 & 223 & 33.45 & 1215 & 36.45 & 1189 & 35.67 & 192 & 26.88 & 173 & 15.57 \\
\hline
\end{tabular}

I=incisor; $C=$ canine; $N H B=$ normal height bone; $B R=$ bone resorption; $W R C=$ wire-composite splint $;$ FRC $=$ fiber-reinforced composite splint; $S G=$ strain gauge; $S D$ - standard deviation

The factorial ANOVA indicated significant differences between the four factors (load distribution, bone condition, bone surface, tooth; $\mathrm{P}<0.001$ ), irrespective of load level. For the 2 -factor interactions, the following interactions were significant for all load values $(\mathrm{P}<0.001)$ : bone condition and load distribution, bone condition and tooth, load distribution and tooth, and bone surface and tooth. Of the 3-factor interactions, only the bone condition, load distribution, and tooth interaction was statistical significant irrespective of load level.

Table 5. Results of factorial ANOVA for data obtained with the four 1 oadings (dependent variable: strain)

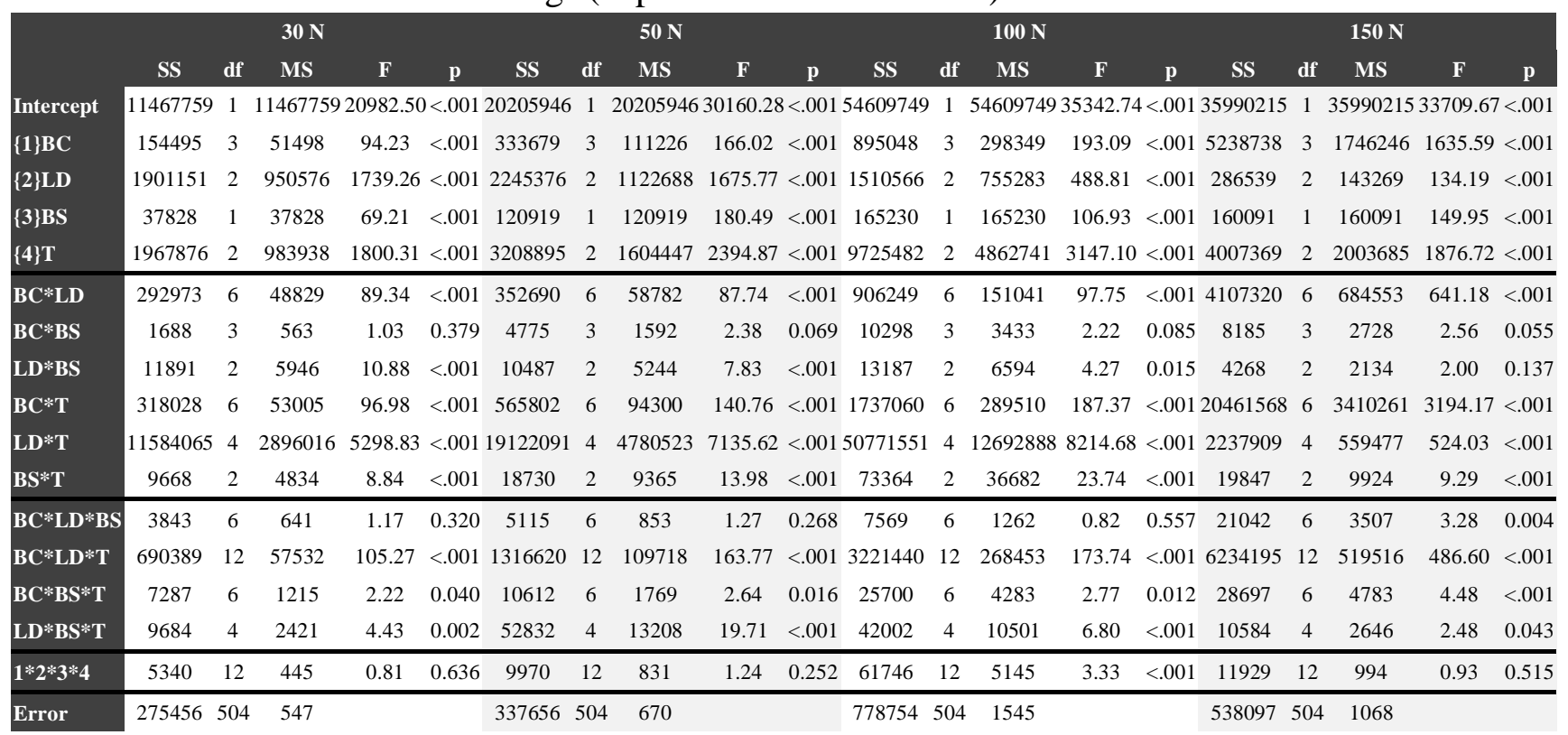

Static tests with maximum compressive force values of $150 \mathrm{~N}$ were performed. The models were subjected to three similar test cycles for each of the above-mentioned situations and the deformation values for four values of the force $(30 \mathrm{~N}, 50 \mathrm{~N}, 100 \mathrm{~N}$ and $150 \mathrm{~N})$ were recorded. These values were chosen because the literature data reported occlusal forces in the anterior mandible region between 40 and $200 \mathrm{~N}[35,36]$. The purpose of the study being bone deformation quantification and not fracture resistance of splints, intermediate physiological loading values were used. These values might not 
describe some particular situations when splints are subjected to much larger forces due to lateral edentulism and consecutive occlusal forces concentration in frontal dental area [8].

Deformations values in the anterior region of the mandible were directly proportional to the load values of the four forces. Even small forces applied cyclically over a period of time, can cause a phenomenon of fatigue or interfere with tissue healing processes, taking into account the small size of the bone structure in this region. In all simulated situations, higher values of deformations were observed on the buccal surface, aspect also reported by Soares et al. This can be explained by a smaller thickness of the labial bone compared to lingual bone [36].

It was noticed that, regardless of the value and of the loaded area, strains in group BR were significantly greater than strains in the group NHB, and those in groups WRC and FRC had intermediate values, but closer to NHB group. In addition, strains at the central incisor were higher by $60-85 \%$ than at the lateral incisor, except when the contact was made on the canine.

Comparing the BR to NHB groups, a severe increase of strains was observed, both on lingual and labial surfaces, the highest difference $(73 \%)$ was recorded for $100 \mathrm{~N}$ force, on buccal for central incisor in $\mathrm{BR}_{2 \mathrm{I}}$ group.

It can be noticed that in the groups with periodontal splinting (WRC and FRC), occlusal forces were distributed to all tooth in the splint, as demonstrated by the modified strain values.

Another quantified parameter with clinical relevance is the tooth contact. When the force is applied to the central incisors, the strains values are $60 \%$ higher than when force is balanced applied at the four incisors.

Another interesting aspect is that when force is applied to the incisors, bone strains in FRC group were higher than in WRC group with no significant differences. This suggests a more elastic behaviour of polyethylene fibers than of the wire-composite system.

When contact was at the canine, comparing the distribution of bone strains from the canine, it was observed that in WRC group the strains were higher by $18 \%$ compared with FRC group, regardless of the force. Due to the intern stiffness of the wire, a reduction in incisors strains can be achieved, which has as disadvantage the consecutive increase of canine strain. In the context of constant overloading, the adaptive level of canine support tissues may be exceeded, thus favouring the progression of bone resorption.

Differences between wire-composite splint and fibre-reinforced composite splints may occur also from clinical behaviour point of view. Thus, the wire - composite resin splint has an interface between two materials with different modules of elasticity (stainless steel and composite resin) without chemical adhesion. Thus, in this area fracture initiation may occur, because the splint exhibits low fatigue strength $[16,25]$.

Regardless the contact between the loading device and the dental surfaces, higher values are observed to lateral incisor in the group BR, versus group NHB, for all four forces. For groups WRC and FRC, horizontal displacement value decreased, but remained higher than in NHB group regardless of force level. No significant differences of displacement values were observed between the two splinting groups. The displacement values in the group $\mathrm{BR}_{2 \mathrm{I}}$ were higher up to $300 \%$ compared to $\mathrm{BR}_{4 \mathrm{I}}$, which reinforce the need of balanced occlusion in order to achieve multiple contacts on the four incisors for an even distribution of occlusal forces.

In a study by Soares et al. [36], based on electric tensometry method, the bone strains were compared when adhesives splinting systems (composite resin, wire resin and fiber-reinforced composites) and wire splinting were applied. The authors noted that bone strains values in case of wire splinting were significant higher compared with the FRC splinting. To a force of $150 \mathrm{~N}$, the wire did not achieved significant stabilization of mobile teeth. According to these results, the use of the wire without application of a composite resin and an adhesive system is not suitable in the splinting periodontal treatment. In the same study, the authors pointed out that dental splints with adhesive system and composite resin produced lower bone strains irrespective of occlusal load. 
The results obtained should be interpreted in the context of the limitations of this study. The tests were performed in vitro so that all parameters of the bone and dento-periodontal substrate could not be reproduced: cortical bone and spongy bone, different bone densities, vascularization, dental innervation, viscoelastic properties of the periodontal ligament [37]. Clinically, other factors as frontal edentulism, employed materials [38], modified prosthetic values of the teeth [39], surface quality of the restorations and teeth [40-44] can influence the biomechanical performance of the splinting system. Also, the compression tests were static without simulating the cyclic, repetitive loads exerted in the oral cavity.

\section{Conclusions}

1. For the groups with periodontal splinting, horizontal displacement values were reduced, but remained higher than in the group with normal bone.

2. Regardless of the load values and distribution, strains in BR group were significantly greater than strains of NHB group and the groups FRC and WRC had intermediate values, but closer to the BR group.

3. In case of bone loss, the bone deformations are up to $110 \%$, regardless of the load value and distribution. Periodontal splinting redistribute forces, reducing incisors bone strains associated with a slight increase in canine bone strains.

4. When a force was applied to the incisors, bone strains in the group FRC were higher than in the group WRC with no significant differences. When force was applied to the canine, regardless of the force value, canine bone strains were higher by $18 \%$ in the WRC compared with FRC group.

5. Periodontal splinting must be correlated with a balanced occlusion, to allow occlusal forces to be applied to an enlarged area, on the four incisors, which allows a strain reduction up to $63 \%$ compared to the situation in which the force is applied only on central incisors.

\section{References}

1NEWMAN, M.G., CARRANZA, F.A., TAKEI, H., KLOKKEVOLD, P.R., Carranza's clinical Periodontology. 10th ed., Elsevier Health Sciences, 2006.

2SAINI, R., MARAWAR, P.P., SHETE, S., SAINI, S. J., Periodontitis, a true infection, Glob Infect Dis., 1(2), 2009, 149.

3.FAN, J., CATON, J.G., Occlusal trauma and excessive occlusal forces: Narrative review, case definitions, and diagnostic considerations, J Periodontol., 89(Suppl 1), 2018, S214- S222, https://doi.org/10.1002/JPER.16-0581.

4SERIO, F.G., HAWLEY, C.E., Periodontal trauma and mobility diagnosis and treatment planning, Dent Clin North Am, 43(1), 1999, 37-44.

5NYMAN, S.R., LANG, N.P., Tooth mobility and the biological rationale for splinting teeth, Periodontol 2000, 4, 1994, 15-22.

6.SERIO, F.G., Clinical rationale for tooth stabilization and splinting, Dent Clin North Am, 43(1), 1999, $1-6$.

7.DAVIES, S.J., GRAY, R.J., LINDEN, G.J., JAMES, J.A., Occlusal considerations in periodontics, Br Dent J., 191(11), 2001, 597-604.

8.GIBBS C.H., ANUSAVICE K.J., YOUNG H.M., JONES J.S., ESQUIVEL-UPSHAW, J.F., Maximum clenching force of patients with moderate loss of posterior tooth support: a pilot study, $J$ Prosthet Dent., 88(5), 2002, 498-502.

9.BOTEZATU, C., DUCEAC, L.D., MASTALIER, B., STAFIE, L., JITAREANU, C.M., LUCA, A.C., TARCA, E., MITREA, G., IORDACHE, A.C., PATRASCU, T., Hepatic Cystic Echinococcosis Studied In A Family Group, International Journal Of Medical Dentistry, 22, 4, 2018, 346-350

10.HALLMON, W.W., HARREL, S.K., Occlusal analysis, diagnosis and management in the practice of periodontics, Periodontol. 2000, 34(1), 2004, 151. 
11.FORABOSCO, A., GRANDI, T., COTTI, B., The importance of splinting of teeth in the therapy of periodontitis, Minerva Stomatol., 55(3), 2006, 87.

12.CORTELLINI, P., TONETTI, M.S., LANG, N.P., SUVAN, J.E., ZUC-CHELLI, G., The simplified papilla preservation flap in the regenerative treatment of deep intrabony defects: clinical outcomes and postoperative morbidity, J Periodontol., 72(12), 2001, 1702-1712.

13.ROSENBERG, S., A new method for stabilization of periodontally involved teeth, J Periodontol., 51(8), 1980, 469-473.

14.BERNAL, G., CARVAJAL, J.C., MUNOZ-VIVEROS, C.A.J., A review of the clinical management of mobile teeth, J Contemp Dent Pract., 3(4), 2002, 10.

15.STOLLER, N.H., GREEN, P.A., A comparison of a composite restorative material and wire ligation as methods of stabilizing excessively mobile mandibular anterior teeth, J. Periodontol., 52(8), 1981, 451-454.

16.TOKAJUK, G., PAWIŃSKA, M., STOKOWSKA, W., WILCZKO, M., KEDRA, B.A., The clinical assessment of mobile teeth stabilization with Fibre-Kor, Med Sci., 51(1), 2006, 225-226.

17.FRIEDMAN, N., Temporary Splinting An Adjunct in Periodontal Therapy, J. Periodontol., 1953, 224-229.

18.LEMMERMAN, K., Rationale for stabilization, J. Periodontol., 47(7), 1976, 405-411.

19.RAMFJORD, S.P, ASH, M.M., Significance of occlusion in the etiology and treatment of early, moderate, and advanced periodontitis, J. Periodontol., 52(9), 1981, 511-517.

20.FERENCZ, J., Splinting, Dent Clin North Am., 31(3), 1987, 383-393.

21.POLLACK, R.P., Non-crown and bridge stabilization of severely mobile, periodontally involved teeth. A 25-year perspective, Dent Clin North Am., 43(1), 1999, 77-103.

22.SIEGEL, S.C., DRISCOLL, C.F., FELDMAN, S., Tooth stabilization and splinting before and after periodontal therapy with fixed partial dentures, Dent Clin North Am., 43(1), 1999, 45-76.

23.KATHARIYA, R., DEVANOORKAR, A., GOLANI, R., SHETTY, N., VALlAKATLA, V., BHAT, M.Y., To Splint or Not to Splint: The Current Status of Periodontal Splinting, J Int Acad Periodontol., 18(2), 2016, 45-56.

24.VALLITTU, P.K., Flexural properties of acrylic resin polymers reinforced with unidirectional and woven glass fibers, J Prosthet Dent., 81(3), 1999, 318-326.

25.DUCEAC, L.D., TARCA, E., CIUHODARU, M.I., TANTU, M.M., GOROFTEI, R.E.B., BANU, E.A., DAMIR, D., GLOD, M., LUCA, A.C., Study on the Mechanism of Antibiotic Resistance, Rev. Chim., 70, 1, 2019, 199-201

26.CAliN, G., MITREA, G., MARCU, C., BURLUI, A., TRUSCA, R., VASILE, E., IACOMI, F., Synthesis and structural characterization of cobalt nanostructures in AAO membranes, Rev. Chim., 70, 9, 2019, 3444-3447

27.CRETEANU, A., OCHIUZ, L., VASILE, C., VIERIU, M., TANTARU, G., Studies On The Influence Of Amiodarone Complexation With Cyclodextrin Derivatives On The In Vitro Release From Matrix Tablets, Farmacia, 65, 4, 2017, 545-549

28.TANTARU, G., POPESCU, M.C., BILD, V. ,POIATA, A., LISA, G., VASILE, C., Spectroscopic, thermal and antimicrobial properties of the copper(II) complex of Schiff base derived from 2(salicylidene) aminopyridine, Applied Organometallic Chemistry, 26, 7, 2012, 356-361. DOI: $10.1002 /$ aoc. 2872

29.DOROFTEI, B., ZLEI, M., SIMIONESCU, G., MAFTEI, R., CUMPATA, S., EMERSON, G., Report of a successful ongoing pregnancy as a result of IMSI with assisted oocyte activation, Reproductive Health, 12, 2015, article 38. DOI: 10.1186/s12978-015-0031-x

30.AnTON, E., BOTNARIUC, N., ANCUTA, E., DOROFTEI, B., CIOBICA, A., ANTON, C., The Importance Of Clinical And Instrumental Diagnostic In The Mammary Gland Cancer, MedicalSurgical Journal-Revista Medico-Chirurgicala, 119, 2, 2015, 410-418

31.:BIBIRE, N., VIERIU, M., TANTARU, G., APOSTU, M., AGOROAEI, L., PANAINTE, A.D.,; ZNAGOVAN, A., VLASE, A., A New and Sensitive LC-MS/MS Method for the Determination of 
Clopidogrel in Human Plasma, Rev. Chim., 65, 7, 2014, 807-810.

32.GRADINARU, I. , BUZEA, C.G., EVA, L., AGOP, M., OCHIUZ, L., SOLOVASTRU, L.G., POPA, R.F., Malignant Invasion Model with Small Amount of Diffusion in the Framework of Scale Relativity Theory, Reviews In Theoretical Science, 3, 4, 2015, 399-417. DOI: 10.1166/rits.2015.1042 33.SEWÓN, L.A., AMPULA, L., VALLITTU, P.K., Rehabilitation of a periodontal patient with rapidly progressing marginal alveolar bone loss: 1-year follow-up, J Clin Periodontol, 27(8), 2000, 615-619.

34.VIERIU, R.M., TANCULESCU, O., MOCANU, F., SOLOMON, S.M., SANDU, I.G., SAVIN, C., BOSINCEANU, D.G., SAVEANU, I.C., SALCEANU, M., APOSTU, A.M., DOLOCA, A., In vitro study regarding the biomechanical behaviour of bone and periodontal splints I. Model validation, Mat. Plast., 56(4), 2019, 1013-1020.

35.HELLSING, G., On the regulation of interincisor bite force in man, J Oral Rehabil., 7(5), 1980, 403-411.

36SOARES, P.B., FERNANDES NETO, A.J., MAGALHÃES, D., VERSLUIS, A., SOARES C.J., Effect of bone loss simulation and periodontal splinting on bone strain: Periodontal splints and bone strain, Arch Oral Biol., 56(11), 2011, 1373-1381.

37.ASUNDI, A., KISHEN, A., A strain gauge and photoelastic analysis of in vivo strain and in vitro stress distribution in human dental supporting structures., Arch Oral Biol., 45(7), 2000, 543-550.

38.VIERIU, R.M., TANCULESCU, O., MOCANU, F., DOLOCA, A., MARTU, S., A Comparative Study of Mechanical Properties of Different Types of Fiber Reinforced Composites Used in Periodontal Therapy, Mater. Plast., 52(2), 2015, 266-271.

39.IOANID, N., IFTENI, G., GRADINARU, I., MÂRȚU, S., TANCULESCU, O., The Prosthetic Value of the Teeth According to their Periodontal Attachment Level, Rom. J. Oral Rehab., 8(2), 2016, 109-114.

40. SOLOMON, S.M., STOLERIU, S., TIMPU, D., AGOP FORNA, D., MARTU STEFANACHE, A., TANCULESCU, O., IOANID, N., MARTU, S., E-SEM Evaluation of Root Surface after SRP with Periotor Tips, Mat. Plast., 53(4), 2016, 796-798.

41.IOVAN, G., STOLERIU, S., PANCU, G., NICA, I., SANDU, A.V., ANDRIAN, S., TANCULESCU, O., Effect of Finishing Techniques on the Junction Between the Composite Restoration and the Dental Enamel, Mat. Plast., 54(2), 2017, 375-379.

42.SAVEANU, C.I., DRAGOS, O., DANILA, V., CHEPTEA, C., Ultrastructural Analysis by Scanning Electron Microscopy of Dental Structures Conditioning with Ortophosphoric Acid and Er.Cr: Ysgg Laser Irradiation, Rev. Chim., 68(1), 2017, 48-51.

43.VIERIU, R.M., TANCULESCU, O., SAVEANU, I.C., CIUR, M.D., BALCOS, C., DOLOCA, A., APOSTU, A., MÂRT,U, S., Clinical Study on Fiber Reinforced Composite and Wire-Composite Periodontal Splinting and their Influence on Periodontal Progress Status, Rom. J. Oral Rehab.,11(4), 2019, 145-151.

44.LUCHIAN, I., NANU, Ș., MARTU, I., TEODORESCU, C., PASARIN, L., SOLOMON, S., MARTU, A.M., TATARCIUC, M., MARTU, S., The Influence of Highly Viscous Flowable Composite Resins on the Survival Rate of Periodontal Splints, Rom. J. Oral Rehab., 10(2), 2018, 63 69.

Manuscript received: 20.01 .2020 